\title{
Financial Stability and its Impact on National Security State: Organizational and Legal Aspects
}

\footnotetext{
Submitted 28/1 1/19, $1^{\text {st }}$ revision 28/12/19, $2^{\text {nd }}$ revision 27/01/20 accepted 03/03/20

Svitlana V. Onyshchuk ${ }^{1}$, Igor I. Onyshchuk ${ }^{2}$, Olha Petroye ${ }^{3}$, Roman Chernysh ${ }^{4}$

\section{Abstract:}

Purpose: This paper analyzes the financial stability, the reasons for the low level of financial stability and their impact on the national security of Ukraine.

Design/Methodology/Approach: By observation, monitoring of causes and effects of financial stability.

Findings: The study found that the main financial stability issues that affected national security in Ukraine were the ineffective regulatory legislation, the high level of distrust in the financial sector, the low growth rates of securities, the high level of credit rates. Also the fact that the financial sector is not capable of securing redistribution of funds in the Ukrainian economy, inefficient use of deposits by the banking sector, insufficient capital of the banking system, low dependence of the banking system on market activity, low level of ability of banks' own capital to cover losses. At the same time banks were exposed to the risk of insolvency of non-financial corporations with insufficient level of money market security and monetization in Ukraine.
}

Practical Implications: A number of problems that negatively affect national security have been systematized. Measures have been developed that will contribute to the development of the financial sector.

Originality/Value: With this article we show that the financial stability of the state, its financial dependency / independence can significantly affect national security, economic security, social security, scientific and technological, military and other types of securities.

Keywords: Financial sustainability, national security, organizational and legal aspects.

JEL Codes: $G 18, E 4, E 5, E 6$.

Paper type: Research article.

\footnotetext{
${ }^{1}$ Doctor of Sciences in Public Administration, Deputy Chairman Regional state administration, Ivano-Frankivsk, Ukraine, E-mail: svikana@meta.ua

${ }^{2}$ Doctor of Sciences in Law, Associate Professor, University "King Danylo", Department of

Theory and History of State and Law, Ivano-Frankivsk, Ukraine, E-mail: revival.if.ua@gmail.com

${ }^{3}$ Doctor of Sciences in Public Administration, Associate Professor, Director of the Institute of Expert-Analytical and Scientific Researches, National Academy for Public Administration under the President of Ukraine, Kyiv, E-mail: petroyeolga@gmail.com ${ }^{4}$ PhD, Associate Professor, Zhytomyr National Agroecological University, Department of Science of Law, Zhytomyr, Ukraine, E-mail: ChernyshRF@gmail.com
} 


\section{Introduction}

National security includes a number of components, including economic security. The financial security of the state is a component of economic security, which is determined by budgetary, tax, investment, monetary, debt and other policies, including the development policy for the financial markets. Financial security is a state of the financial system of a country under which the necessary financial conditions for stable socio-economic development of the country are created, its stability to financial shocks and imbalances is ensured, conditions are created for preserving the integrity and unity of the country's financial system. Financial security includes banking security, non-banking security, debt security, budgetary security, and monetary security.

Financial sustainability is determined, on the one hand, by the policies of the financial system regulators to which Ministry of Finance of Ukraine, National Bank of Ukraine primarily belong, and, on the other, the efficiency of the country's financial institutions and non-financial institutions.

\section{Literature Review}

Financial instability affects economic development and national security. The financial crisis of 2008-2009 is an example of such an impact when poor financial stability in the country has led to a decline in the level of welfare of the population. Despite the importance of financial stability studies of communication and their impact on national security, the scientific literature does not sufficiently studied and highlighted this connection, particularly in Ukraine. The work of Brüha and Kočenda (2018) examines the financial stability of European countries, the impact of outstanding loans on the level of sovereign risk. A significant correlation was found between country financial sector risks and bank capital adequacy, banking sector diversification in foreign banks and high level of competition.

The financial stability of the banking sector is procyclical. This conclusion was made in the work of Bouheni and Hasnaoui (2017). Increased lending can increase the risks of instability in the financial system and capital accumulation raises financial stability (Thalassinos and Thalassinos, 2018). It should also be noted the pro-cyclical nature of the impact of small banks' lending and capital on financial stability and counter cyclicality in the case of large banks (Rupeika-Apoga et al., 2018; Thalassinos et al., 2015).

Monetary policy has a significant impact on the state of the financial system and its sustainability. The discount rate is a tool for achieving financial sustainability that prevents the country from accumulating financial risks. The central bank's regulatory policies have a significant impact on the banking sector, which can be considered one of the main sectors of financial stability. Bank diversification and financial stability are linked by non-linear relationships. A moderate degree of diversification 
has a positive effect on financial stability, whereas an excessive degree has a negative effect (Kim et al., 2019). Particularly important is the bank diversification in times of financial crisis, when fluctuations in financial stability can increase. The financially sound banking sector is less vulnerable to the impact of economic or political factors. At the same time, the country's economy must be strong to ensure financial stability, as demonstrated in Samitas, Polyzos and Siriopoulos (2018).

Ineffective regulatory policies can lead to increased financial risks in the country, such as the penetration of foreign banks in the absence of restrictions on their activities, harsh capital outflows, ineffective recommendations for asset diversification, lack of oversight bodies, high barriers to entry, and other barriers to entry. Central bank macroprudential policies always have an impact on financial stability. In particular, this was explored in Klingelhöfer and Sun (2019) in the case of China, which identified an immediate and ongoing impact on lending, maintaining financial stability without slowing economic growth. The policy is a complement to monetary policy to offset financial risks. The study by Rubio and Comunale (2018) also links macro-prudential policies with macroeconomic and financial stability in Lithuania and the rest of the Eurozone.

The goal of the Central Banks of the Eurozone countries is financial stability, and the national macro-prudential policy is an effective tool for achieving it. Such an objective should be complementary to NBU policy in a context where the financial sector is sensitive to shocks, as in the case of Ukraine. Agur and Demertzis (2019) noted that monetary policy, even in the context of macro-prudential supervision, affects financial stability (in particular capital regulation, banking risks and the financial market) by regulating interest rates. In the short term, macro-prudential policies help to divert inflation from the Central Bank's inflation target, while monetary policy can help boost lending. At the same time, macro-prudential policy also contributes to stabilizing inflation and monetary to financial stability (Kima and Mehrotra, 2017). Obviously, the regulatory activity of the Central Bank ensures the financial stability of the country, which has a non-linear effect on economic security.

Thus, the balance of macro-prudential and monetary policies of the Central Bank is to ensure financial stability, as a consequence of macroeconomic stability and national security. The impact of optimal macroprudential policy on growth and prosperity is small, but it increases financial stability (Ma, 2019). Mester (2017) argues that macro-prudential oversight focuses on risk management in the financial system. Macro-prudential policy instruments are a priority for ensuring the country's financial stability, and monetary policy instruments are an important complement to them. The macro-prudential policy tool is Central Bank communication, which should ensure transparency (disclosure of information) in order to ensure financial stability.

Mendonçaab and Moraes (2019) study demonstrates the effectiveness of Central Bank communications to enhance financial stability, an indicator of which is credit 
risk. Ongoing communications of the Central Bank regarding the expectations in the credit market, the financial market contributes to financial stability, as a result of the country's investment attractiveness, the development of the banking and financial sectors. A similar view is highlighted in the work of Horváth (2016), which demonstrates the positive impact of Central Bank transparency on financial stability. In turn, high levels of financial volatility have a negative effect on Central Bank transparency as a non-linear relationship.

Given the NBU's policy of inflation targeting in Ukraine, it is important to determine its impact on financial sustainability. A study by Fazioa et al. (2018) found an increase in financial imbalances in terms of inflation targeting due to the poor quality of institutions and lack of confidence of the Central Bank. A similar situation in Ukraine has been observed since independence. Since 2015, the NBU has significantly increased its institutional capacity, and confidence in the banking sector has increased. These trends are relevant to the study of the state of financial stability in Ukraine and its relation to the economic security and national security of the country as a whole.

\section{Methodology and Data}

The financial sustainability of a state can be assessed through a system of indicators. According to the definition of the National Bank of Ukraine (2019), indicators of financial stability of the state are "indicators of the current financial condition and stability of financial institutions of the country and their counterparties in the corporation and household sectors." Therefore, in order to further assess the state of financial soundness in Ukraine, the analysis of financial soundness indicators will be carried out according to the National Bank of Ukraine.

The article uses the indicators of development of the financial system of Ukraine, which reflect the state of financial stability, for the period 2000-2018 in the context of the following institutions: International Monetary Fund, National Bank of Ukraine and World Bank. Due to the lack of data for certain periods of time (especially data in 2018), financial stability was assessed based on qualitative indicators of financial system development. The main indicators of financial stability were:

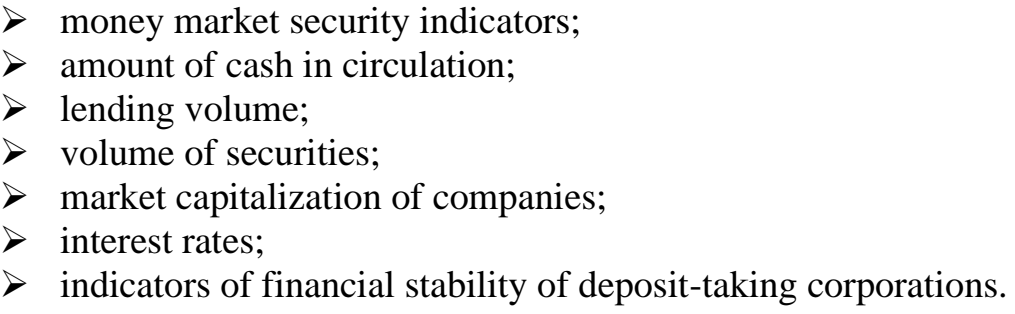

The study used the following methogological methods: observation, monitoring of causes and effects of financial stability. 


\section{Financial Sector Development in Ukraine}

The financial sector of the Ukrainian economy reflects information on interest rates in the financial market (credit, deposit, interbank, securities), the national currency rate, the volume of loans and deposits. The development of the financial sector over the last ten years has been characterized by discretion and disproportionality. The banking sector was a major segment of the financial sector, growing at a much higher rate than other segments, including bond and equity market issues, and the issue of securities by mutual investment institutions. Lack of regulatory legislation and effective institutions, prudential oversight of the non-banking financial sector led to the emergence of "captive" institutions and financial pyramids, deepened the crisis in the sectors, hampered its development, led to an increase in confidence in the financial sector as a whole. Accordingly, the level of financial stability remained low, which in the conditions of the financial crisis had a negative impact on the national security of Ukraine.

The efficiency of financial sector management is reflected by the monetary base of Ukraine, which includes cash in circulation, transferable deposits and other deposits that determine the level of prices and the level of liquidity in the Ukrainian economy. These indicators are regulated by the NBU. Therefore, the required reserves in Ukraine are constantly increasing. At the same time, during the financial crises, there was a significant increase in cash in circulation (in 2007-2008 by $48 \%$ and $39 \%$ respectively, in $2013-2014$ by $17 \%$ and $19 \%$ respectively), while the economic recovery led to a significant slowdown in growth cash in the economy of Ukraine. At the same time, the M1 aggregate grew at an economic growth due to an increase in transferable deposits, which occurred at a faster rate, mainly at the economic downturn. In 2017, transferable deposits grew at a faster rate, which may indicate an increase in the overall volume of non-cash payments. In addition, over the 2000-2018 period, M2 and M3 are at almost the same level, which indicates that there is no significant increase in the volume of securities in Ukraine.

\section{Development of the Monetary Sector of Ukraine}

It is important to characterize the share of cash in the amount of money (ratio of M0 to M3), which in the developed countries is at the level of $3-9 \%$ (Bozhanova, 2016; Ignatova and Kasyan, 2013). In Ukraine, the share of cash averaged 31\% from 2001 to 2018 , reaching a maximum in 2001 and a minimum of $26 \%$ in $2012-2013$. This indicates that one third of the funds is outside the banking sector, which is a negative trend, since the financial sector does not fully lend to the real sector of Ukraine. This indicates a high level of distrust in the banking sector, a high level of inflation and a lack of efficiency in the financial sector as a whole.

Figure 1 shows the dynamics of the security level of functioning of the money market of Ukraine, as the dynamics of the ratio of M0 to GDP and the level of monetization of the Ukrainian economy, as the ratio of M2 to GDP. The normative 
value is $4 \%$, while in Ukraine the average ratio of M0 to GDP was $14 \%$ from 2001 to $2017, \mathrm{M} 2$ to GDP $47 \%$. The accepted normative value is $4 \%$ (Ignatova and Kasyan, 2013).

Figure 1. Dynamics of the level of money market security and monetization in Ukraine in 2001-2017,\%

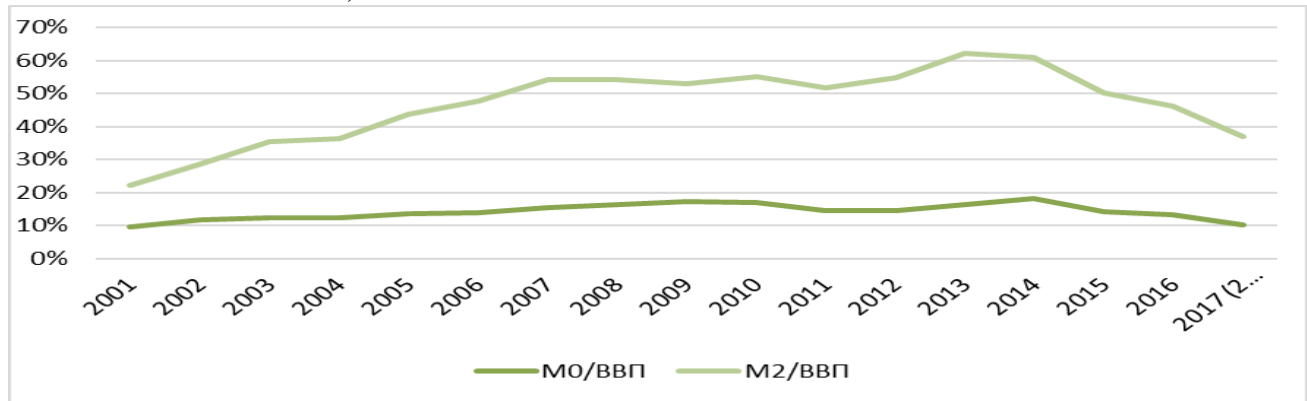

Source: International Monetary Fund, 2019.

The high value of the level of monetization indicates a high demand for real money in Ukraine, while in developed countries it is 70-80\% (Bova, 2015).

In developed countries, the level of lending to the economy is much higher than in developing countries, which means that the financial sector is capable of redistributing capital. Therefore, in 2001-2018, Ukraine has seen significant fluctuations in lending to the economy, which is why the financial sector, dependent on the global environment, is in the making stage, and financial crises immediately affect the slowdown in lending to the economy. Accordingly, this causes a low level of financial stability in the country.

Foreign direct investment attracts financial sector development and low levels of macroeconomic fluctuations in developed countries. Thus, in Ukraine, the size of foreign direct investment (FDI) attraction is low compared to that in EU countries. The low level of development of the financial sector of Ukraine in comparison with European countries is evidenced by the dynamics of market capitalization of companies listed on stock exchanges. Therefore, the actual public offering of shares of Ukrainian companies took place only in 2008-2008 and in 2010-2011. Instead, financial markets in Europe are driven by the development of stock exchanges and the transparency of their operations (for example, the London Stock Exchange is the most developed in Europe). Thus, the market capitalization of companies in the EU averaged 61\% in 2001-2018, 88\% in the world, $45 \%$ in Germany, $79 \%$ in Spain, and $78 \%$ in France. Therefore, this testifies to the greater efficiency of the financial sector in EU countries. The financial sector that ensures the functioning of the financial services market remains fragmented, characterized by a low level of capitalization, volatile business conditions, an insecure property rights institute, and a low level of corporate governance. 
Figure 2. Dynamics of interest rates in Ukraine in 2001-2018 years, \%

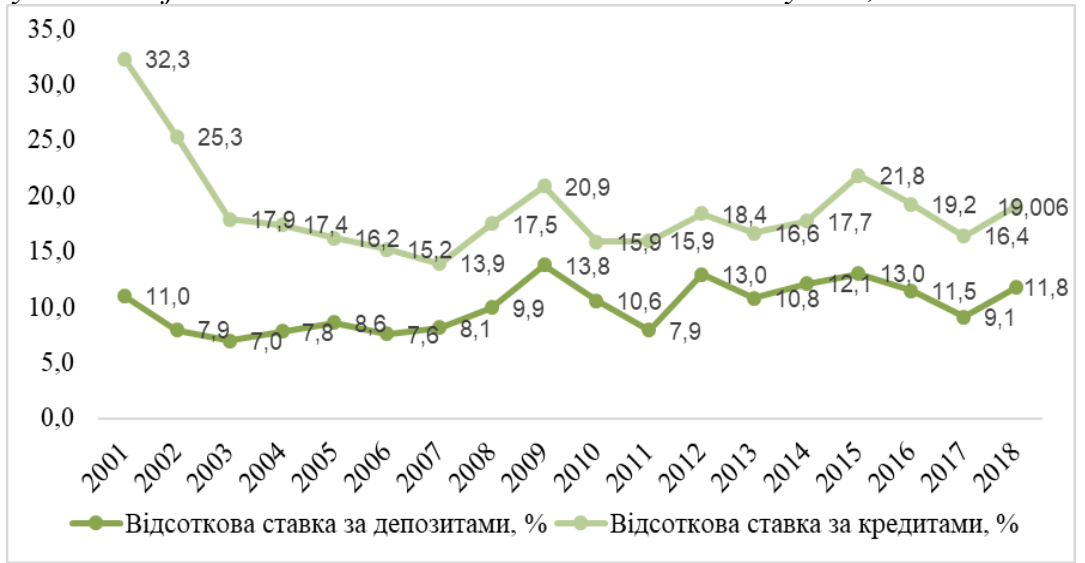

\section{Source: World Bank Financial Sector https://data.worldbank.org/indicator.}

One of the negative factors of insufficient level of lending to the real sector is the high level of interest rates (Figure 2), which leads to high cost of credit resources, and macroeconomic problems and risks cause high risks of non-repayment of credit resources by economic agents, as a consequence of securing financial resources in the economy of Ukraine. This is another confirmation of Ukraine's low financial sustainability.

Figure 3. Interrest rates loss of credit operations and lending

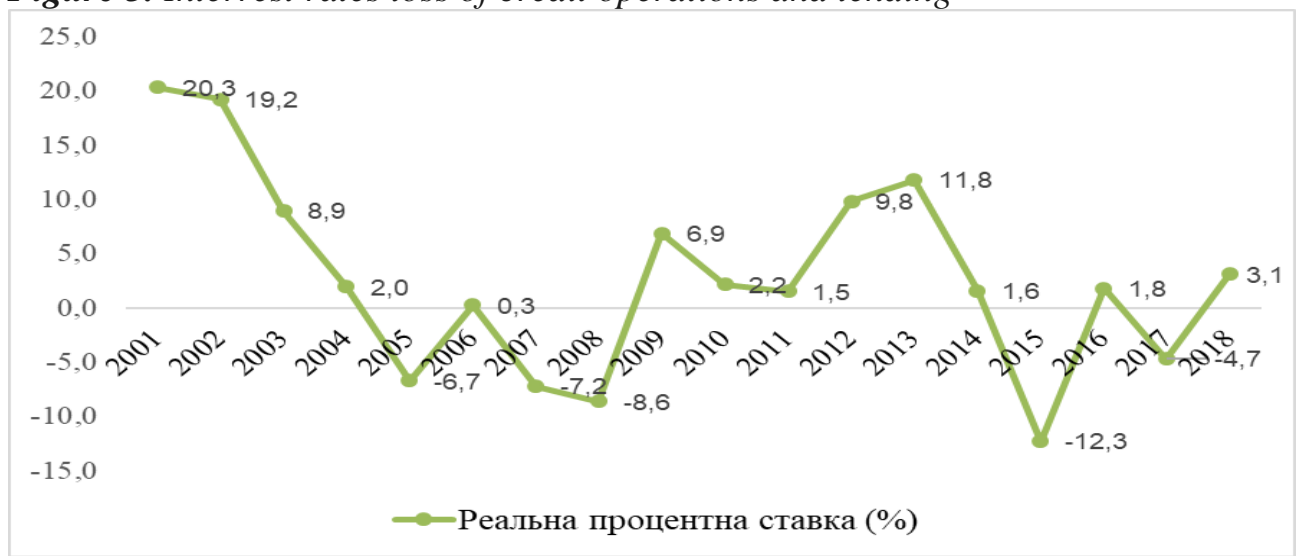

Source: World Bank, 2019.

Significant fluctuations in the real interest rate indicate a high level of inflation in Ukraine, which is why the cost of lending to the banking sector at a negative interest rate actually led to a loss of credit operations and lending (Figure 3). Accordingly, the macroeconomic problem, which has a high inflation rate, has a negative impact on the development of Ukraine's financial sector. 
Compared with EU countries the financial sector in Ukraine finances the activities of economic agents at a low level, since on average, domestic loans accounted for $67.7 \%$ of GDP in 2001-2018, while in EU countries $143.4 \%$. In Germany is $137.4 \%$, in Italy $139.0 \%$, in Belgium 118.7\%, in Spain 189.6\%, in France 132.5\%, in Greece $119.7 \%$, in the Netherlands $188.8 \%$.

\section{Evaluation of Financial Stability of the Financial Sector}

Analysis of the financial sustainability indicators is appropriate: 1) assess the vulnerability of the financial sector; 2) assess the status of the non-financial sectors; 3) monitor financial sector vulnerabilities caused by credit risk, liquidity risk and market risk; 4) assess the financial sector's ability to absorb losses, for example, as determined by equity ratios (Indicators of financial stability, 2007) (Table 1):

Table 1. Dynamics of financial stability indicators of Ukraine in 2013-2018

\begin{tabular}{|c|c|c|c|c|c|c|}
\hline Indicators & 2013 & 2014 & 2015 & 2016 & 2017 & 2018 \\
\hline \multicolumn{7}{|c|}{ Major EMF of deposit-taking corporations } \\
\hline $\begin{array}{l}\text { Ratio of regulatory capital to risk- } \\
\text { weighted assets }\end{array}$ & 18,26 & 15,60 & 12,31 & 12,69 & 16,10 & 16,18 \\
\hline $\begin{array}{l}\text { Ratio of level regulatory capital to } \\
\text { risk-weighted assets }\end{array}$ & 13,89 & 11,21 & 8,30 & 8,96 & 12,12 & 10,52 \\
\hline $\begin{array}{l}\text { Ratio of non-performing loans } \\
\text { excluding capital reserves }\end{array}$ & 30,65 & 61,07 & 129,02 & 89,37 & 70,18 & 60,20 \\
\hline $\begin{array}{l}\text { Ratio of non-performing loans to } \\
\text { total gross loans }\end{array}$ & 12,89 & 18,98 & 28,03 & 30,47 & 54,54 & 52,85 \\
\hline \multicolumn{7}{|l|}{$\begin{array}{l}\text { Ratio of loans by economic sectors } \\
\text { to total gross loans }\end{array}$} \\
\hline Share in total gross loans: Residents & 98,72 & 96,05 & 94,54 & 95,92 & 94,21 & 93,47 \\
\hline $\begin{array}{l}\text { Share in total gross loans: Deposit- } \\
\text { taking corporations }\end{array}$ & 1,99 & 1,14 & 0,72 & 0,49 & 0,54 & 0,90 \\
\hline $\begin{array}{l}\text { Share in total gross loans: Central } \\
\text { Bank }\end{array}$ & 0,00 & 0,00 & 0,00 & 0,00 & 0,00 & 0,00 \\
\hline $\begin{array}{l}\text { Share in total gross loans: Other } \\
\text { financial corporations }\end{array}$ & 2,05 & 2,38 & 1,49 & 1,11 & 1,01 & 0,80 \\
\hline $\begin{array}{l}\text { Share in total gross loans: General } \\
\text { government sector }\end{array}$ & 0,63 & 0,46 & 0,32 & 0,14 & 0,14 & 0,25 \\
\hline $\begin{array}{l}\text { Share in total gross loans: Non- } \\
\text { financial orporations }{ }^{3}\end{array}$ & 73,48 & 72,42 & 75,29 & 78,55 & 76,47 & 74,16 \\
\hline $\begin{array}{l}\text { Share in total gross loans: Other } \\
\text { resident sectors }\end{array}$ & 20,57 & 19,65 & 16,72 & 15,63 & 16,06 & 17,36 \\
\hline $\begin{array}{l}\text { Share in total gross loans: Non- } \\
\text { residents }\end{array}$ & 1,28 & 3,95 & 5,46 & 4,08 & 5,79 & 6,53 \\
\hline Rate of return on assets & 0,26 & $-4,24$ & $-5,54$ & $-12,47$ & $-1,76$ & 1,60 \\
\hline Rate of return on capital & 1,72 & $-31,95$ & $-65,51$ & $-122,17$ & $-15,34$ & 14,61 \\
\hline $\begin{array}{l}\text { Ratio of interest margin to gross } \\
\text { income }\end{array}$ & 58,56 & 48,46 & 39,00 & 45,94 & 50,20 & 52,02 \\
\hline $\begin{array}{l}\text { Ratio of non-interest expenses to } \\
\text { gross income }\end{array}$ & 65,95 & 59,85 & 54,40 & 60,91 & 76,14 & 61,92 \\
\hline Ratio of liquid assets to total assets & 20,63 & 26,40 & 33,00 & 48,53 & 53,94 & 51,14 \\
\hline
\end{tabular}




\begin{tabular}{|l|l|l|l|l|l|l|}
$\begin{array}{l}\text { Ratio of liquid assets to short-term } \\
\text { liabilities }\end{array}$ & 89,11 & 86,14 & 92,87 & 92,09 & 98,37 & 93,52 \\
\hline $\begin{array}{l}\text { Ratio of the net open position in } \\
\text { foreign currency to equity }\end{array}$ & 6,94 & 31,69 & 136,03 & 118,88 & 89,61 & 134,77 \\
\hline
\end{tabular}

Source: National Bank of Ukraine, 2019.

The ratio of regulatory capital to risk-weighted assets (an average of $15.19 \%$ for 2013-2018) indicates problems with capital adequacy and risks in the financial sector of Ukraine, as the banking system cannot cover its own losses on its own because of insufficient equity. The ratio of non-performing loans excluding capital reserves indicates a low level of banks' equity to cover losses (an average of $73.42 \%)$.

The ratio of non-performing loans to total gross loans indicates a low level of asset quality, ie., the funds attracted by the banking sector were used inefficiently, $32.96 \%$ of the loans in 2013-2018 were unpaid, and therefore banks were exposed to the risk of insolvency of non-financial corporations management. At the same time, in 2008 it was the lowest value of $4 \%$, as the level of lending decreased significantly.

The ratio of loans by economic sectors to total gross loans indicates that on average $95.49 \%$ of banking sector loans are concentrated in non-residents, in particular $75 \%$ in 2013-2018, on average, in non-financial corporations, and this leads to significant risks for the financial sector because the high concentration of credit banking resources making the banking system vulnerable to financial turmoil.

The rate of return on assets averaged $-3.69 \%$, due to the low level of equity. The return on equity is also low and negative during 2013-2018 (-36.44\%). The high risks of the Ukrainian banking system are associated with high leverage and also associated with a low interest margin to gross margin ratio, driven by high interest rates on banks.

The ratio of liquid assets to total assets is an indicator of distrust in the banking system and indicates its vulnerability to financial crises. In 2016-2017 alone, the indicator value was $48.53 \%$ and $53.94 \%$ respectively. This was the reason for the lack of liquidity of the banking system and led to the insolvency of most banks in times of crisis. The ratio of liquid assets to short-term liabilities averaged $92.02 \%$, gradually increasing in 2015-2018.

The ratio of capital to assets of deposit-taking corporations of Ukraine (banks) is at a low level and indicates a lack of capital in the banking system. The ratio of loans by geographical distribution to total gross loans indicates that Ukrainian banks lend 97\% to the average domestic economy. The spread between loan and deposit rates (basis points) indicates a high underlying profitability of the Ukrainian banking sector, as the indicator's average was 617.96 points in 2013-2018. 
The ratio of trading income to gross income of 8.54 points on average indicates a low dependence of the banking system on market activity. The ratio of staff maintenance costs to non-interest costs of $40.66 \%$ indicates their effectiveness. The ratio of customer deposits to total gross loans (excluding interbank ones) was $68.43 \%$. Such an attitude may indicate a potentially tense liquidity situation in the banking system, and possibly a loss of confidence for investors and investors in the long-term viability of the sector. At the same time, this ratio was the lowest during the economic downturn.

\section{Disscussion}

During the period under review, the following trends of the financial sector of Ukraine have been identified, which indicate low financial stability:

- banking sector is a major segment of the financial sector, which is growing at a faster rate than other segments;

- lack of regulatory legislation and effective institutions, prudential oversight of the non-banking financial sector;

- level of distrust in the financial sector as a whole increased by 2014-2015, after which the NBU managed to suspend these processes and restore confidence;

- distrust of the financial sector is growing in the face of the financial crisis, which causes low levels of financial stability that adversely affect the national security of Ukraine;

- increase in the required reserves together with a significant increase in cash in circulation during the financial crises, while the economic recovery leads to a significant slowdown in the growth of cash in the Ukrainian economy;

- there is no significant growth in the volume of securities in Ukraine, which indicates a low level of development of the securities market, and therefore the financial sector, which ensures the functioning of the financial services market, remains fragmentary, characterized by low level of capitalization, instability of business conditions, unprotected institute of property rights, low level of corporate governance;

- one third of the funds are outside the banking sector, which is why the financial sector does not fully lend to the real sector of Ukraine;

- Ukraine has experienced significant fluctuations in lending to the economy in 2001-2018, which is why the financial sector, dependent on the global market, is in its infancy, and financial crises immediately affect the slowdown in lending to the economy. Accordingly, this causes a low level of financial stability in the country; - one of the negative factors behind the insufficient level of lending to the real sector is the high level of interest rates;

- financial sector is not capable of securing redistribution of funds in the Ukrainian economy. This is another confirmation of Ukraine's low financial sustainability.

Considering the statistics of the financial sector of Ukraine in the near future, one can expect a revival and gradual slow development, in particular in the conditions of 
macroeconomic stability. The main regulator of the financial sector is the National Bank of Ukraine, whose policy depends on the development of the main financial segment - the banking sector. Given the integration of Ukraine, it can be expected gradual liberalization, a weakening of the state regulatory pressure on the financial sector, and the development of institutions that will facilitate its development. Important regulatory measures should be:

Providing equal access to the financial services market, clearing systems and financing mechanisms;

$>\quad$ Ensuring equal access of creditors, investors to entities providing financial services;

Financing and development of e-government;

$>\quad$ Currency liberalization, lifting of currency restrictions, liberalization of credit operations and portfolio investment;

Strengthening solvency and liquidity requirements of financial sector borrowers;

$>\quad$ Implementation of the macro-prudential policy and oversight strategy;

$>\quad$ Implementation of risk-based supervision of financial sector entities.

These measures will contribute to the development of the financial sector. Otherwise, the identified problems will constrain the growth of the financial sector capitalization, lending to the real economy financial sector, the growth of deposits, the stock market and corporate bonds. In addition, these activities will allow for the following years:

Reduce inflation and ensure consumer price stability at $5-7 \%$.
Reduce the level of cash in the economy of Ukraine to $9-10 \%$.
Increase the level of retail non-cash payments up to $30-40 \%$.
Reduce the level of dollarization of the economy to $35-40 \%$.
Provide a reduction in interest rates on loans up to $12-13 \%$.
Increase the security of the Ukrainian money market to 5-7\%
compared to $14 \%$.
Increase of level of monetization of economy in Ukraine to 50-60\%.

\section{Conclusion}

The study analyzes the financial sustainability of Ukraine, systematizes a number of problems that adversely affect national security. The analysis of the financial stability of Ukraine is carried out, a number of problems that negatively affect national security have been systematized. The main systemic problems are: lack of regulatory legislation and effective institutions; prudential supervision of the nonbanking financial sector; instant increase in the level of mistrust of the population in the financial crisis which causes a low level of financial stability that adversely affects the national security of Ukraine; increase in the required reserves together 
with a significant increase in cash in circulation during the financial crises, while the economic recovery leads to a significant slowdown in the growth of cash in the Ukrainian economy; low level of development of the securities market, and the financial services market is fragmented, characterized by low level of capitalization; instability of business conditions; unprotected institute of ownership; low level of corporate governance; one third of the funds are outside the banking sector, which is why the financial sector does not fully lend to the real sector of Ukraine; significant fluctuations in lending to the economy are observed; the financial sector, which is dependent on the global environment, is in its infancy, and the financial crises are affecting the slowdown in lending to the economy; there is a high level of interest rates.

Due to these numerous problems, the financial sector is not able to ensure the redistribution of funds in the Ukrainian economy.

\section{References:}

Agur, I., Demertzis, M. 2019. Will macroprudential policy counteract monetary policy's effects on financial stability? The North American Journal of Economics and Finance, 48, 65-75.

Bouheni, F.B., Hasnaoui, A. 2017. Cyclical behavior of the financial stability of eurozone commercial banks. Economic Modelling, 67, 392-408.

Bova, N.V. 2015. Dynamics of changes in the money supply and its influence on the formation of the deposit policy of the bank. Young scientist, 10(25), 91-94.

Bozhanova, O.V. 2016. Analysis of the state of money supply in Ukraine. Young scientist, 3(30), 19-23.

Brůha, J., Kočenda, E. 2018. Financial stability in Europe: Banking and sovereign risk. Journal of Financial Stability, 36, 305-321.

Degl'Innocenti, M., Grant, K., Šević, A., Tzeremesd, N.G. 2018. Financial stability, competitiveness and banks' innovation capacity: Evidence from the Global Financial Crisis. International Review of Financial Analysis, 59, 35-46.

Fazioa, D.M., Silva, T.Ch., Tabak, B.M., Cajueiro, D.O. 2018. Inflation targeting and financial stability: Does the quality of institutions matter? Economic Modelling, 71, 1 15.

Horváth, R. 2016. Central bank transparency and financial stability. Journal of Financial Stability, 22, 45-56.

Ignatova, O.M., Kasyan, O.V. 2013. Statistical analysis of cash circulation in Ukraine and its impact on the value of the national currency. Economy and the state, 6, 53-56.

International Monetary Fund. 2007. Financial sustainability indicators. Compilation Guide. Washington, DC, https://www.imf.org/external/pubs/ft/fsi/guide/2006/pdf/rus/guide.pdf.

International Monetary Fund. 2019. Surveys Based on Standardized Report Forms (SRFs) by Country available at http://data.imf.org/regular.aspx?key=61545858.

Kim, H., Batten, J.A., Ryu, D. 2019. Financial crisis, bank diversification, and financial stability: OECD countries. International Review of Economics \& Finance, 65, 94-104.

Kima, S., Mehrotra, A. 2017. Managing price and financial stability objectives in inflation targeting economies in Asia and the Pacific. Journal of Financial Stability, 29, 106116. 
Klingelhöfer, J., Sun, R. 2019. Macroprudential policy, central banks and financial stability: Evidence from China. Journal of International Money and Finance, 93, 19-41.

$\mathrm{Ma}, \mathrm{Ch}$. 2019. Financial stability, growth and macroprudential policy. Journal of International Economics. Available at https://doi.org/10.1016/j.jinteco.2019.103259.

Mendonçaab, H.F., Moraes, C.O. 2019. Central bank disclosure as a macroprudential tool for financial stability. Economic Systems, 42(4), 625-636.

Mester, L.J. 2017. The nexus of macroprudential supervision, monetary policy, and financial stability. Journal of Financial Stability, 30, 177-180.

National Bank of Ukraine. 2019. Financial financials indicators and background data. Available at https://bank.gov.ua/statistic/sector-financial/data-sector-financial\#4fsi.

National Bank of Ukraine. 2019. Statistics of financial stability indicators. Available at https://bank.gov.ua/control/uk/publish/article?art_id=58001\&cat_id=44444.

Rubio, M., Comunale, M. 2018. Macroeconomic and financial stability in a monetary union: The case of Lithuania. Economic Systems, 42(1), 75-90.

Rupeika-Apoga, R., Zaidi, H.S., Thalassinos, E.Y., Thalassinos, I.E. 2018. Bank Stability: The Case of Nordic and Non-Nordic Banks in Latvia. International Journal of Economics and Business Administration, 6(2), 39-55.

Samitasa, A., Polyzos, S., Siriopoulos, C. 2018. Brexit and financial stability: An agentbased simulation. Economic Modelling, 69, 181-192.

Thalassinos, I.E., Thalassinos, E.Y. 2018. Financial Crises and e-Commerce: How Are They Related? Available at SSRN: https://ssrn.com/abstract=3330169.

Thalassinos, I.E., Stamatopoulos, D.T. and Thalassinos, E.P. 2015. The European Sovereign Debt Crisis and the Role of Credit Swaps. Chapter book in The WSPC Handbook of Futures Markets (eds) W. T. Ziemba and A.G. Malliaris, in memory of Late Milton Miller (Nobel 1990) World Scientific Handbook in Financial Economic Series Vol. 5, Chapter 20, pp. 605-639, ISBN: 978-981-4566-91-9, (doi: 10.1142/9789814566926_0020).

World Bank. 2019. Financial Sector. Available at https://data.worldbank.org/indicator.

Yin, H. 2019. Bank globalization and financial stability: International evidence. Research in International Business and Finance, 49, 207-224. 